\title{
Absorption of pteroylpolyglutamates in mothers of infants with neural tube defects
}

\author{
BY CAROL BOWER, FIONA J. STANLEY, MAXINE CROFT \\ AND NICHOLAS H. DE KLERK \\ Western Australian Research Institute for Child Health, Princess Margaret Hospital for Children, \\ GPO Box D 184, 6001, Western Australia, Australia \\ AND RICHARD E. DAVIS AND DARRYL J. NICOL \\ Department of Haematology, Royal Perth Hospital, GPO Box X2213, Perth 6001, \\ Western Australia, Australia
}

(Received 27 January 1992-Accepted 16 July 1992)

\begin{abstract}
The ability to hydrolyse and absorb pteroylpolyglutamates (PteGlu ${ }_{n}$ ) included in a standard meal in mothers who had given birth to an infant with a neural tube defect was tested by comparing them with mothers who had not had any infants with this defect. When compared with control mothers working in the research unit in which the study was performed, case mothers had significantly lower baseline serum and erythrocyte folate levels, and smaller increases in serum folate following the meal containing PteGlu $\mathrm{n}_{\mathrm{n}}$ However, all estimates of folate were similar when case mothers were compared with a group of mothers who were friends of the case mothers. The results show that the higher the baseline levels of serum and erythrocyte folate the greater the increase in serum folate after the test meal. Fitting a model for the serum folate response curve resulted in coefficients which differed significantly between case mothers and all control mothers. We conclude that intestinal hydrolysis of PteGlu $\mathrm{u}_{\mathrm{n}}$ taken orally is not impaired in mothers who have had infants with neural tube defects when compared with control mothers with similar baseline folate levels, although the curves describing the response to the meal for the two groups do differ significantly. Further investigation is required to determine the mechanism underlying this difference.
\end{abstract}

Folic acid: Neural tube defects: Infants

Dietary folate exists naturally as a mixture of pteroylpolyglutamates $\left(\mathrm{PteGlu}_{\mathrm{n}}\right)$ which must be enzymically converted in the small intestine to pteroylmonoglutamate (PteGlu) before absorption can take place (Rosenberg, 1976; Halsted, 1979).

Several observational studies of neural tube defects (NTD) have implicated vitamins, particularly folic acid, as a possible preventive measure if taken periconceptionally (Smithells et al. 1980; Laurence et al. 1981; Mulinare et al. 1988; Milunsky et al. 1989). A multicentre randomized trial has now demonstrated a $72 \%$ reduction in the recurrence of NTD following periconceptional folic acid supplementation (Medical Research Council Vitamin Study Group, 1991).

A case-control study of NTD in Western Australia showed a protective effect of increasing intake of dietary folate in early pregnancy (Bower \& Stanley, 1989). The effect was more marked for PteGlu than for PteGlu plus PteGlu (total folate). Because of errors in the food tables used to estimate the amounts of folate in the diet (Phillips et al. 1982), the differences observed in this study between PteGlu and total folate may simply have been due to misclassification bias, as we have already suggested (Bower \& Stanley, 1989). 
Another suggested explanation for this finding was that an inability to hydrolyse PteGlu in the gut may be an underlying genetic mechanism for relative folate deficiency in mothers whose infant had an NTD.

In order to test this hypothesis, the following study was conducted to compare the hydrolysis and absorption of PteGlu $\mathrm{u}_{\mathrm{n}}$ in mothers who had had an infant or fetus with an NTD (case mothers) with mothers whose infants had not had such a defect (control mothers).

\section{METHODS}

Case mothers were ascertained from two sources: the Western Australian Birth Defects Registry, and the Spina Bifida Association of Western Australia (Inc). The Registry is a population-based register with multiple sources of case-ascertainment (Bower \& Stanley, 1983). From the Registry, the mothers of infants with isolated NTD born in 1988 and who lived in metropolitan Perth were invited to participate in the study. Members of the Spina Bifida Association were informed of the study by the coordinator of the Association, and those volunteering to take part were sent the same letter of invitation as the mothers identified from the Registry. Mothers whose infants had multiple defects or a known syndrome in association with the NTD were not eligible for inclusion. There were two control groups. The first was a group of volunteer mothers from the Research Unit in which the study was being conducted, none of whom had had an infant with NTD. Because of the possibility of the research group differing from the case mothers on a number of variables such as social class, a second control group was also included. For this group, each case mother who agreed to participate was asked if she had a friend who might be willing also to participate, as a control. It was explained that the friend should be similar to the case mother in terms of socio-economic circumstances, to reside in the metropolitan area, to have had at least one pregnancy, and not to have had an infant with NTD. Mothers who were currently pregnant were ineligible for inclusion in the study. The study was approved by the Human Rights Committee of the University of Western Australia.

Case mothers were asked to do the test twice. On the first occasion the research volunteers were also studied. On the second occasion, 5 months after the first, the case mothers and their friends were studied.

Twelve case mothers participated in the study on the first occasion. Eighteen infants with isolated NTD born in 1988 and whose mothers were resident in metropolitan Perth were identified from the Birth Defects Registry. Four mothers were unable to be traced, five were currently pregnant, and two were ill at the time of the study. Two mothers did not wish to participate, and the remaining five mothers took part in the study on the first occasion. Seven members of the Spina Bifida Association volunteered to participate. Two mothers had had an infant or fetus with anencephaly, and nine had had an infant with spina bifida (one mother had had two fetuses affected with spina bifida), and one mother had had one infant with spina bifida and one with anencephaly. A total of eleven volunteers from the Research Unit took part in the study at this time.

For the second round of tests, three of the case mothers were unable to participate. One mother unable to take part in the first test took part in the second. Thus, there were ten case mothers, eight of whom invited a friend to participate with them. Because of a shortage in the supply of the folate meal, the two mothers who did not invite a friend consumed the energy and protein mixture without added folate. Compared with the baseline level of serum folate immediately before consuming the meal, the serum folate in these two mothers was at or below the baseline level at each of the sampling times following consumption of the meal, thus confirming the absence of folate in the substrate of the meal.

The mean maternal age for the case mothers was 32.6 years, for the friend controls it was 
34.7 years, and for the research controls it was 40.0 years. The case mothers had had an average of 1.9 births, the research controls 1.8 births, and the friend controls had had an average of 2.5 births. All case mothers and their friends ate an omnivorous diet. Two of the research controls were vegetarian, the remainder being omnivorous. No mother was taking folate supplements, and seven were taking oral contraceptives (three case mothers, one friend control and two research control mothers).

All mothers agreeing to participate were visited at home or at work by a research nurse, when a $10 \mathrm{ml}$ sample of venous blood was taken for baseline serum and erythrocyte folate determination. At that time, mothers completed a short questionnaire recording their usual diet and any drugs or vitamin supplements taken in the preceding week. A $5 \mathrm{mg}$ tablet of folic acid BP was taken by the mother immediately after the first sample of blood had been drawn. This was to load the tissues before the meal so that the serum folate levels would reflect hydrolysis and/or absorption rather than rapid transit into body tissues. Preliminary studies indicated that the rise in serum folate following a $5 \mathrm{mg}$ oral dose of folic acid persists for more than $7 \mathrm{~d}$ (R. E. Davis, unpublished results).

After 1 week the mothers fasted overnight and attended the Haematology Department of Royal Perth Hospital early next morning. A fasting sample of $5 \mathrm{ml}$ venous blood was taken. Serum folate was estimated in this and all subsequent blood samples. The mothers then consumed a specially prepared meal containing yeast extract equivalent to $4.5 \mathrm{mg}$ $\mathrm{PteGlu}_{7}$ in $10 \mathrm{ml}$ water. This dose was of the same order as that used in previous studies (Keagy et al. 1988) and was shown in preliminary work to produce a significant rise in serum folate in normal volunteers. It was followed by $300 \mathrm{ml}$ of a mixture of polycose powder, whole milk, egg white and vanilla, which provided a source of energy and protein without additional folate. This was chosen to approximate the usual dietary situation.

The PteGlu $\mathrm{n}_{\mathrm{n}}$ extract was obtained by heating Torula yeast with aqueous sodium ascorbate. Concentration of the folate was achieved by lyophilization. The PteGlu content of the extract was determined microbiologically using Lactobacillus casei as the test organism (Davis et al. 1970). This organism does not respond to folates containing more than three glutamic acid residues. After treating the extract with pteroylpolyglutamyl hydrolase from chicken pancreas to convert all folate to PteGlu ${ }_{2}$, total folate was assayed and compared with the pre-enzyme treatment assay. This showed that PteGlu $\mathrm{n}_{\mathrm{n}}$ constituted $93 \%$ of the total folate in the extract.

Blood samples were taken at hourly intervals after consumption of the meal. Determination of serum and erythrocyte folate levels was made using an automated microbiological method with a chloramphenicol-resistant mutant strain of $L$. casei (Davis et al. 1970), and the results expressed as $\mu \mathrm{g}$ PteGlu equivalents/l. Sera with known folate concentrations were included at regular intervals together with a number of blind sample duplicates to assess assay variation. The method has a coefficient of variation of less than $5 \%$ for duplicate analyses.

Comparisons were made between case mothers on the first test results and research controls, and between case mothers at the second test and their friend controls, using a twosample $t$-test with unequal variances. Logarithmic transformation of the data and nonparametric tests did not produce results which differed importantly from the results of the $t$-tests and, hence, only the latter have been presented.

Various mathematical models were applied to the data measuring the response to the meal, but these were only developed after examination of the data. We wanted to find a sample model that had biological plausibility, that had been applied to similar biological systems, and that equally well described the response of both sets of controls.

The method used in fitting models was to assume some form of equation for the individual response and then find the best overall values of the variables of the equation 
Table 1. Values obtained in the first tests for serum and erythrocyte folate $(\mu g / l)$ for mothers who had had an infant or fetus with a neural tube defect (case mothers) and control mothers*

(Mean values and standard deviations)

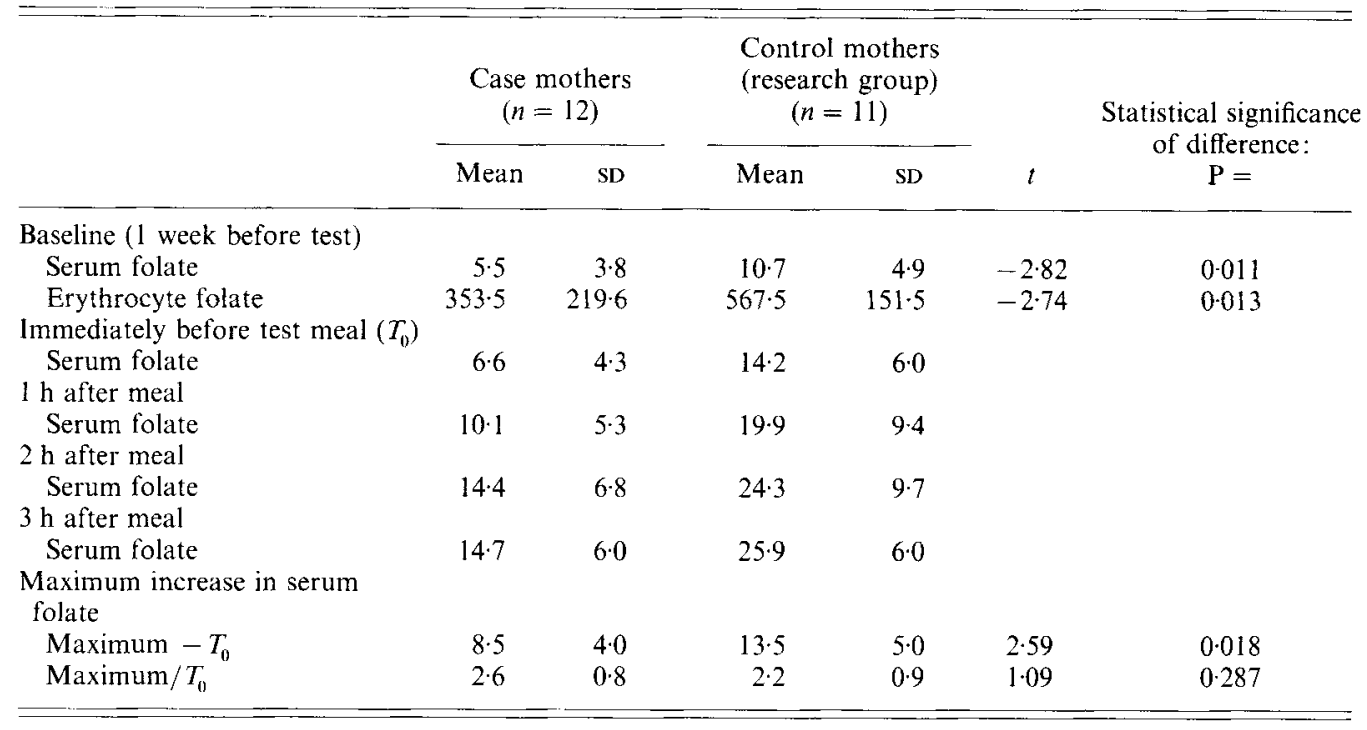

* For details of subjects, see pp. 828-829.

using the least-squares criterion. Residual sums of squares were examined for systematic differences either by control group or time period and also for individual outliers. Systematic differences implied that a model was inappropriate. Details of the modelling are described later (pp. 831-832).

\section{RESULTS}

The results of the first test comparing case mothers with controls from the research group are shown in Table 1. Baseline folate estimates from samples taken 1 week before the test meal were significantly different. The mean rise in serum folate from this time to immediately before the test meal was greater for controls than for cases (mean rise $1 \cdot 1 \mu \mathrm{g} / 1$ for case mothers $3.5 \mu \mathrm{g} / 1$ for controls; $t-2.34, P=0.032$ ). At each time of measurement, serum folate was greater for controls than for case mothers. The maximum serum folate level observed over the test period was $15.1 \mu \mathrm{g} / 1$ for case mothers and $27.7 \mu \mathrm{g} / 1$ for controls. The absolute maximum increase in serum folate (calculated by subtracting the value immediately before consumption of the test meal from the maximum value) was significantly greater in the controls than the case mothers (Table 1). The relative increase, which was calculated by dividing the maximum value by the initial value, was similar for case mothers and controls.

Results for the second set of tests, comparing case mothers with their friends, are shown in Table 2. Baseline folate values and values after consumption of the PteGlu $\mathrm{u}_{n}$ meal did not differ significantly between case mothers and controls. The mean increase in serum folate from 1 week before the test meal to immediately before the meal was $0.7 \mu \mathrm{g} / 1$ for case mothers, and $1.4 \mu \mathrm{g} / 1$ for control mothers $(t-0.94, P=0.364)$.

Similar comparisons were made between case mothers on the two occasions of testing, and between the research group controls and the friend controls. There were no significant 
Table 2. Values obtained in the second tests for serum and erythrocyte folate $(\mu \mathrm{g} / \mathrm{l})$ for mothers who had had an infant or fetus with a neural tube defect (case mothers) and control mothers*

(Mean values and standard deviations)

\begin{tabular}{|c|c|c|c|c|c|c|}
\hline & \multicolumn{2}{|c|}{$\begin{array}{l}\text { Case mothers } \\
\quad(n=8)\end{array}$} & \multicolumn{2}{|c|}{$\begin{array}{c}\text { Control mothers } \\
(\text { friends }) \\
(n=8)\end{array}$} & \multirow[b]{2}{*}{$t$} & \multirow{2}{*}{$\begin{array}{l}\text { Statistical significance } \\
\text { of difference: } \\
\mathbf{P}=\end{array}$} \\
\hline & Mean & SD & Mean & SD & & \\
\hline \multicolumn{7}{|c|}{ Baseline ( 1 week before test) } \\
\hline Serum folate & 4.8 & 1.5 & $5 \cdot 2$ & $2 \cdot 1$ & 0.43 & 0.674 \\
\hline Erythrocyte folate & $279 \cdot 4$ & 81.8 & $367 \cdot 0$ & $157 \cdot 2$ & 1.27 & 0.233 \\
\hline \multicolumn{7}{|c|}{$\begin{array}{l}\text { Immediately before test meal } \\
\left(T_{0}\right)\end{array}$} \\
\hline Serum folate & 5.5 & $1 \cdot 4$ & $6 \cdot 6$ & $2 \cdot 3$ & & \\
\hline \multicolumn{7}{|l|}{$1 \mathrm{~h}$ after meal } \\
\hline \multirow{2}{*}{\multicolumn{7}{|c|}{$2 \mathrm{~h}$ after meal }} \\
\hline & & & & & & \\
\hline Serum folate & $11 \cdot 3$ & $3 \cdot 3$ & $12 \cdot 2$ & $5 \cdot 0$ & & \\
\hline \multicolumn{7}{|l|}{$3 \mathrm{~h}$ after meal } \\
\hline Serum folate & $13 \cdot 1$ & $4 \cdot 5$ & $13 \cdot 0$ & $5 \cdot 1$ & & \\
\hline \multicolumn{7}{|c|}{$\begin{array}{l}\text { Maximum increase in serum } \\
\text { folate }\end{array}$} \\
\hline Maximum $-T_{0}$ & $7 \cdot 6$ & $3 \cdot 9$ & 6.6 & $4 \cdot 4$ & 0.49 & 0.633 \\
\hline $\operatorname{Maximum} / T_{0}$ & $2 \cdot 4$ & $0 \cdot 7$ & $2 \cdot 1$ & 0.7 & 1.01 & 0.329 \\
\hline
\end{tabular}

* For details of subjects, see pp. 828-829.

differences between the cases on the two occasions, and the research controls were significantly different from the friend controls for all the measures in which they were also different from the case mothers.

The findings were similar when mothers taking oral contraceptives were excluded from the analysis (details not shown).

All values for serum folate measured $0.5 \mathrm{~h}$ after the meal at the second set of tests were intermediate between the initial and the maximum folate levels.

One simple explanation for the increase in serum folate being proportional to the initial value would be: low circulating levels of folate imply low levels in essential body stores so that when the circulating level rises the folate is absorbed more rapidly by the stores, but this rate of absorption decreases as the level in the stores approaches some optimum level. This means that the rises across all groups were roughly constant on a logarithmic scale.

The simplest equation that we found for describing this process that fitted the data and that was similar to other models developed in similar systems (for example, see Finkelstein \& Carson, 1985), was:

or

$$
\begin{gathered}
d x / d t=x(b-2 c t), \\
x=x_{0} \exp \left(a+b t-c t^{2}\right),
\end{gathered}
$$

where $x$ is the serum folate level, $t$ is time (h) after ingestion, $x_{0}$ is the usual circulating level estimated by the very first value, and $a, b$, and $c$ are constants to be estimated.

The difference between the baseline level and the fasting level is represented by $a, b$ represents the absorption of folate from the gut into the serum and $c$ represents the uptake of folate from the serum by tissues. 
Equation 1 gives a maximum for $x$ at $b=2 c t$. Fixing $t$ at 2.5 implies that $b=5 c$, since examination of the individual response curves indicated that a peak value of serum folate occurred at about $2.5 \mathrm{~h}$ after the meal.

Fitting this model to the two control groups separately resulted in very similar estimates for $a, b$ and $c$. There were no systematic differences in the residuals when the model was fitted to the data from both control groups combined.

The resulting coefficients of this model were: $a 0 \cdot 10$ (SE 0.01), $b 0.51$ (SE 0.04), $c 0.10$ (SE 0.02 ). However, the best fit to the cases (on the first occasion) gave values: $a 0.09$ (SE 0.01 ), $b 0.66$ (SE 0.05), $c 0.13$ (SE 0.02). Both the $b$ and $c$ terms were higher for the case group than for the control group: $b P=0.03, c P=0.2$.

Examination of individual response plots for all mothers indicated that the general form of the response was one of a delayed rise to a peak not inconsistent with the $2.5 \mathrm{~h}$ found in the experiments with deconjugated folate of Lucock et al. $(1989 a, b)$ followed by a decline.

\section{DISCUSSION}

All mothers in the present study showed a rise in serum folate after administration of a PteGlu $_{n}$ meal, demonstrating that intestinal hydrolysis had occurred, at least to some extent. There was no evidence from the present study to suggest that mothers who had had an infant with NTD were less able to hydrolyse and absorb dietary folate when compared with control mothers from similar social circumstances, and with similar baseline serum and erythrocyte folate, but who had not had an infant with NTD. However, mothers in the research control group had significantly higher baseline levels of serum and erythrocyte folate, and higher maximum levels of serum folate following consumption of the meal containing PteGlu $u_{n}$, when compared with either the case group or their friends. The rise in serum folate following the $5 \mathrm{mg}$ loading dose of folic acid BP was also greater for the controls from the research group than from either of the other two groups of mothers.

The research group was, on average, slightly older than the other two groups, but there is evidence to suggest that age does not affect folate absorption (Bailey et al. 1984). None of the mothers was pregnant, and oral contraceptives did not account for the difference (Davis \& Smith, 1974). Although there are several reported inborn errors of folate metabolism (Erbe, 1975a,b), no genetic defects of pteroylpolyglutamate hydrolase activity have been documented (McKusick, 1986). Our findings suggest that the higher the baseline serum (or erythrocyte) folate the greater the level of serum folate following folic acid supplements or a PteGlu meal. While no evidence of a feedback mechanism has been documented, plasma levels of folate are influenced by absorption, haemodynamics, tissue stores and plasma clearance (Selhub et al. 1983). If stores are replete, as might be expected in the research group with high erythrocyte folate, then absorbed folate may remain in the circulation longer and lead to higher serum levels of folate, as has been observed. The converse would be that in those subjects with low tissue stores (the case mothers and their friends), despite the loading dose, absorbed serum folate is rapidly removed from the circulation and taken up by the tissues. This has been reported by others (Smithells, 1983) and seems a more plausible explanation for our findings than the possibility that absorption of folate is reduced as a result of low baseline serum or erythrocyte folate.

Two-thirds of the subjects had their highest measured levels of folate recorded at the last sampling time in our study ( $3 \mathrm{~h}$ after the meal) and, hence, it is possible that serum folate continued to rise after this time. However, other studies of PteGlu absorption indicate a peak serum folate level at $2.5 \mathrm{~h}$ (Lucock et al. 1989 a). Although our subjects consumed PteGlu $_{n}$, our findings are consistent with a peak at this time. There is evidence that intestinal hydrolysis is rapid and that absorption is the rate-limiting step (Rosenberg, 1976), 
and there is no reason to suspect that these findings would not be present during pregnancy (McLean et al. 1970).

If deconjugation were impaired in case mothers compared with the controls we would expect the $b$ value in our model to be less in case mothers than in controls. However, the opposite was found indicating a more rapid absorption of folate. Because we have fixed $t$ at $2.5 \mathrm{~h}$ the relationship between $b$ and $c$ is also fixed. Thus, it is not possible to establish whether the difference in absorption is between the gut and the serum, the serum and the stores, or due to differences in both stages of absorption.

Some abnormality of folate metabolism, in mothers (as suggested by the present study and by Yates et al. 1987) or possibly in fetuses, may be an underlying mechanism in the etiology of NTD. Periconceptional supplementation of mothers with folate may raise the tissue reserves to an optimal level, overcome this metabolic difference, and lead to a reduction in NTD in their offspring, as the Medical Research Council trial has demonstrated for recurrent NTD (Medical Research Council Vitamin Study Group, 1991). Further investigation is required to determine the mechanism.

The authors are grateful to the Spina Bifida Association (WA Branch) for their enthusiasm and support for the study, and to all participating mothers. Their thanks go to Melanie Seward for assistance in coordinating the study, and to Edwina Rudy for contacting the mothers and collecting the first blood samples. They thank Associate Professor Roma Bell for her advice on the consumption of the standard meal and Andrea Chamberlain for help in meal preparation during the study. Thanks are also due to the staff in the Haematology Department, Royal Perth Hospital, for assistance in the collection of the blood samples and performing the folate assays, and to Dr Barry Garner for statistical assistance and advice. The study was funded by a grant from the Princess Margaret Hospital Research Foundation.

\section{REFERENCES}

Bailey, L. B., Cerda, J. J., Bloch, B. S., Busby, M. J., Varge, S. L., Chandler, C. J. \& Halstead, C. H. (1984). Effect of age on poly- and monoglutamyl folacin absorption in human subjects. Journal of Nutrition 114, 1770-1776.

Bower, C. \& Stanley, F. J. (1983). Western Australian Congenital Malformations Register. Medical Journal of Australia 2, $189-191$.

Bower, C. \& Stanley, F. J. (1989). Dietary folate as a risk factor for neural tube defects, evidence from a casecontrol study in Western Australia. Medical Journal of Australia 150, 613-619.

Davis, R. E., Nicol, D. J. \& Kelly, A. (1970). An automated method for the measurement of folate activity. Journal of Clinical Pathology 23, 42-53.

Davis, R. E. \& Smith, B. K. (1974). Pyridoxal, vitamin B12 and folate metabolism in women taking oral contraceptive agents. South African Medical Journal 48, 1937-1940.

Erbe, R. W. (1975a). Inborn errors of folate metabolism. New England Journal of Medicine 293, $753-757$.

Erbe, R. W. (1975 b). Inborn errors of folate metabolism. New England Journal of Medicine 293, 807-811.

Finkelstein, L. \& Carson, E. R. (1985). Mathematical Modelling of Dynamic Biological Systems 2nd ed. Letchworth: Research Studies Press Ltd.

Halsted, C. H. (1979). The intestinal absorption of folates. American Journal of Clinical Nutrition 32, $846-855$.

Keagy, P. M., Shane, B. \& Oace, S. M. (1988). Folate bioavailability in humans: effects of wheat bran and beans. American Journal of Clinical Nutrition 47, 80-88.

Laurence, K. M., James, N., Miller, M. H., Tennant, G. B. \& Campbell, H. (1981). Double-blind randomized controlled trial of folate treatment before conception to prevent recurrence of neural-tube defects. British Medical Journal 282, 1509-1511.

Lucock, M., Wild, J., Smithells, R. \& Hartley, R. (1989a). Biotransformation of pteroylmonoglutamic acid during absorption, implications of Michaelis-Menten kinetics. European Journal of Clinical Nutrition 43, 631-635.

Lucock, M., Wild, J., Smithells, R. W. \& Hartley, R. $(1989 \mathrm{~b})$. In vivo characterization of the absorption and biotransformation of pteroylmonoglutamic acid in man, a model for future studies. Biochemical Medicine and Metabolic Biology 42, 30-42.

McKusick, V. A. (1986). Mendelian Inheritance in Man, 7th ed. Baltimore: Johns Hopkins University Press.

McLean, F. W., Heine, M. W., Held, B. \& Streiff, R. R. (1970). Folic acid absorption in pregnancy: Comparison of the pteroylpolyglutamate and pteroylmonoglutamate. Blood 36, 628-631. 
Medical Research Council Vitamin Study Research Group (1991). Prevention of neural tube defects: results of the Medical Research Council Vitamin Study. Lancet 338, 131-137.

Milunsky, A., Jick, H., Jick, S., Bruell, C., MacLaughlin, D. S., Rothman, K. J. \& Willett, W. (1989). Multivitamin/folic acid supplementation in early pregnancy reduces the prevalence of neural tube defects. Journal of the American Medical Association 262, 2847-2852.

Mulinare, J., Cordero, J. F., Erickson, J. D. \& Berry, R. J. (1988). Periconceptional use of multivitamins and the occurrence of neural tube defects. Journal of the American Medical Association 260, 3141-3145.

Phillips, D. R., Wright, A. J. A. \& Southgate, D. A. T. (1982). Values for folates in foods. Lancet ii, 1172.

Rosenberg, I. H. (1976). Absorption and malabsorption of folates. Clinics in Haematology 5, 589-618.

Selhub, J., Dhar, G. J. \& Rosenberg. I. H. (1983). Gastrointestinal absorption of folates and antifolates. Pharmacology and Therapeutics 20,397-418.

Smithells, R. W. (1983). Prevention of neural tube defects by vitamin supplements. In Prevention of Spina Bifida and Other Neural Tube Defects, p. 60 [J. Dobbing, editor]. London: Academic Press.

Smithells, R. W., Sheppard, S., Schorah, C. J., Seller, M. J., Nevin, N. C., Harris, R., Read, A. P. \& Fielding, D. W. (1980). Possible prevention of neural tube defects by periconceptional vitamin supplementation. Lancet $\mathbf{i}$, 339-340.

Yates, J. R. W., Ferguson-Smith, M. A., Shenkin, A., Guzman-Rodriguez, R., White, M. \& Clark, B. J. (1987). Is disordered folate metabolism the basis for the genetic predisposition to neural tube defects? Clinical Genetics 31, 279-287. 